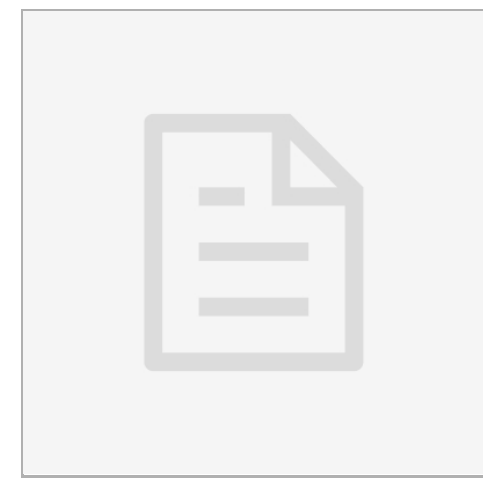

OCT 21, 2019

open ठACCEss

DOI:

dx.doi.org/10.17504/protocol s.io.8jbhuin

Protocol Citation: Niels Appelman 2019. Encasing LAMP mixture in paraffin. protocols.io

https://dx.doi.org/10.17504/p rotocols.io.8jbhuin

License: This is an open access protocol distributed under the terms of the Creative Commons Attribution License, which permits unrestricted use, distribution, and reproduction in any medium, provided the original author and source are credited

Protocol status: Working We use this protocol and it's working

Created: Oct 21, 2019

Last Modified: Oct 21, 2019

PROTOCOL integer ID:

28995

1 Prepare a 10X primermix according to the following scheme

\begin{tabular}{|l|l|}
\hline Prime & $\begin{array}{l}\text { Conc } \\
\text { entrat } \\
\text { ion }\end{array}$ \\
\hline
\end{tabular}

\section{(3) Encasing LAMP mixture in paraffin}

Niels Appelman ${ }^{1}$

${ }^{1}$ Wageningen University

iGEM Wageningen 2019

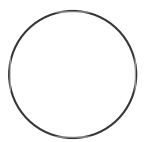

Niels Appelman

Wageningen University

\section{ABSTRACT}

This protocol can be used to encase LAMP mastermix and primers in paraffin. 


\begin{tabular}{|c|c|}
\hline FIP & $\begin{array}{c}16 \\
\mu \mathrm{M}\end{array}$ \\
\hline BIP & $\begin{array}{l}16 \\
\mu \mathrm{M}\end{array}$ \\
\hline F3 & $2 \mu \mathrm{M}$ \\
\hline B3 & $2 \mu \mathrm{M}$ \\
\hline $\begin{array}{l}\text { LOOP } \\
\mathrm{F}\end{array}$ & $8 \mu \mathrm{M}$ \\
\hline $\begin{array}{l}\text { LOOP } \\
\text { B }\end{array}$ & $8 \mu \mathrm{M}$ \\
\hline
\end{tabular}

2 Add the following components to a micro centrifuge tube

\begin{tabular}{|l|l|l|}
\hline Component & Volume added \\
\hline Mastermix & $5 \mathrm{ul}$ \\
\hline $\begin{array}{l}\text { Lamp } \\
\text { primers (10X) }\end{array}$ & $1 \mathrm{ul}$ \\
\hline
\end{tabular}

3 Open the centrifuge tube and let dry at $37 \mathrm{C}$ until only solid is left.

Note: The longer this step takes, the more activity the enzyme loses. It is recommended to dry in a storage area with a low humidity, as to speed up this step. To minimize the loss of activity, lyophilisation is recommended.

$4 \quad$ Add 4 mg of paraffin wax

5 Heat at $60 \mathrm{C}$ for 5 minutes to let the wax melt and encapsulate the dried LAMP mixture

6 After the wax dries, the continued activity of the enzyme can be tested. To do this, add the following components 


\begin{tabular}{|l|l|}
\hline Component & Volume added \\
\hline Template & $\begin{array}{l}\mathrm{X} \\
\mathrm{uL}\end{array}$ \\
\hline MilliQ & $\begin{array}{l}10 \\
-\mathrm{x} \mathrm{uL}\end{array}$ \\
\hline
\end{tabular}

7 Incubate at $65 \mathrm{C}$ for 30 minutes

8 Record the color of all samples. Yellowing of a sample indicates a positive result.

9 In case of doubt regarding the result of a sample, run it on an agarose gel. The presence of many bands, often not individually recognizable, indicates a positive result. 